\title{
Influence of Climate Factors and Plant Varieties on the Hay Technology (Fibrous Feed)
}

\author{
Victor Adrian BĂRBIERU ${ }^{1}$, Mihai OLAR ${ }^{1 *}$, Ovidiu RANTA ${ }^{1}$, Mircea MUNTEAN ${ }^{1}$, Ovidiu MARIAN ${ }^{1}$, \\ Laurenț OGNEAN² ${ }^{2}$, Georgiana CĂTUNESCU ${ }^{1}$ \\ ${ }^{1}$ Faculty of Agriculture, University of Agricultural Sciences and Veterinary Medicine Cluj-Napoca, Calea \\ Mănăştur 3-5, 400372, Cluj-Napoca, Romania \\ ${ }^{1}$ Faculty of Veterinary Medicine, University of Agricultural Sciences and Veterinary Medicine Cluj- \\ Napoca, Calea Mănăștur 3-5, 400372, Cluj-Napoca, Romania \\ * corresponding author: mihai.olar@gmail.com
}

Bulletin UASVM series Agriculture 73(2)/2016

Print ISSN 1843-5246; Electronic ISSN 1843-5386

DOI 10.15835/buasvmcn-agr: 12404

\begin{abstract}
The present study was carried on the Research and Didactical Station Jucu located close to Someş River. The aim of the study is to determine the fuel consumption and productivity of aggregates (machineries) used in the conditions of the two levels of hay production technology. The experimental plot uses Festuca Arundinacea, while control, spontaneous vegetation (Dactilys glomerata 70\%, Alopecurus pratensis 10\% Festuca sp.6\%, Trifolium repens $5 \%$, other plants $9 \%$ ). Grassland soil taken in study type is molded with a high coefficient of withering (16$19 \%$ ) and a small capacity water output (8\%). Chemical characteristics of soil samples shows us a good content in humus and good to very good in mobile potassium, being deficient in phosphorus mobile. The differences noted between the fuel consumptions for the two parcels is due to higher vegetable production of control plot which has also a running speed of different aggregates also influencing effective productivity.
\end{abstract}

Keywords: gathering, meadows plots, mowing; scattering.

\section{INTRODUCTION}

Research has taken place on the grounds of the Research and Didactical Station Jucu located close

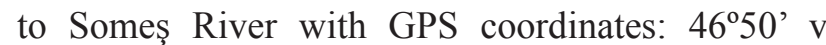
and $23^{\circ} 45^{\prime}$ E. Physical conditions of this place are in climatic frame named Trans-Carpathian area, with an altitude between 280 and 360 meters. The study tracked the average temperatures, rain sum and soil type, with physical and chemical features, samples being taken from the meadow located on Someş River floodplain (Bărbieru, 2006; MolnarIrimie, 2016). The aim of this study is to determine the fuel consumption and productivity of aggregates (machineries) used in the conditions of the two levels of hay production technology (Dobre et al., 2014). In this purpose, we used to plots: experimental and control, respectively (Bungescu and Popa, 2007).

\section{MATERIALS AND METHODS}

The two plots on which we have conducted the experiments are:

- Experimental Plot (Fig. 1) sown Festuca Arundinacea $\left(2^{\text {nd }}\right.$ year of vegetation) being sown in the spring of 2013 with $\{$ Vio Jucu $\}$ seed, sowing with $35 \mathrm{~kg} / \mathrm{ha}$ seed, land preparation were an autumn ploughing at 25-27 cm deep and in the spring it was harrowing before sowing. Sowing depth of $1.5 \mathrm{~cm}$ and after sowing we use a roller machine for the contact of seeds with the ground, resulted in a rapid and uniform of the raising of meadow, in the second year we have an average production of 28.5 to/ha.

- Control plot (Fig. 2) with spontaneous vegetation (Dactilys glomerata 70\%, Alopecurus 


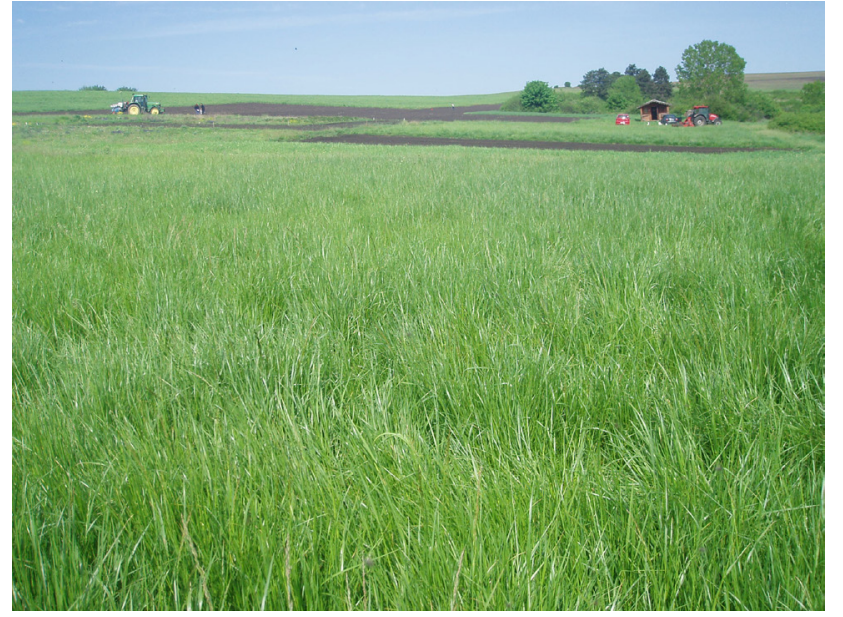

Fig. 1. Experimental plot (Festuca arundinacea)

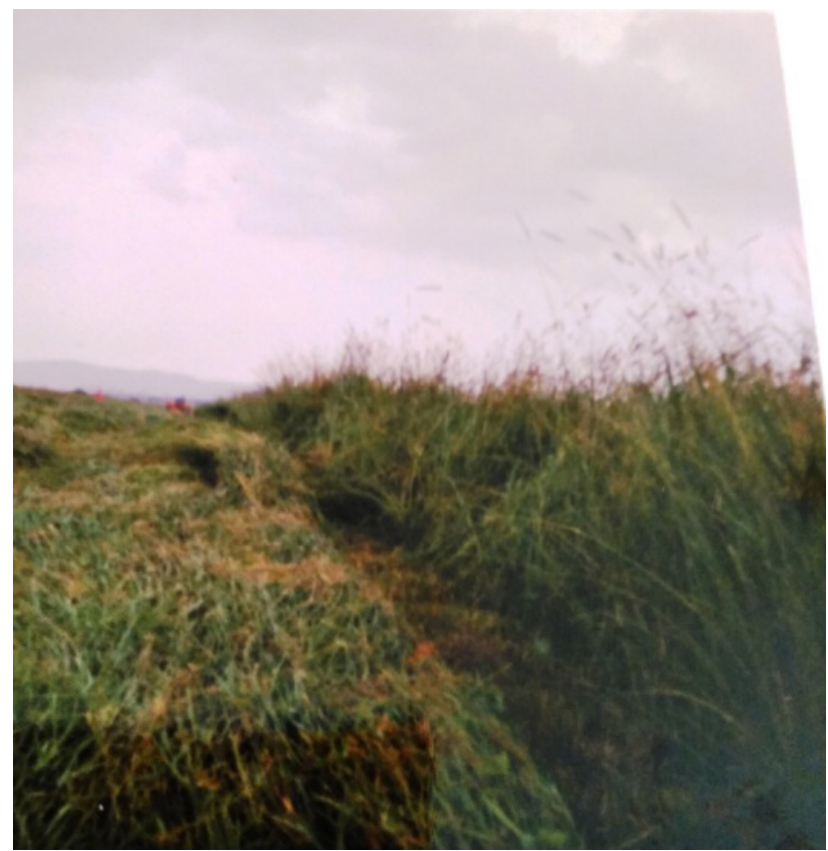

Fig. 2. Control plot (spontaneous vegetation)

pratensis $10 \% \quad$ Festuca sp.6\%, Trifolium repens $5 \%$, other plants $9 \%$ ), with a vegetal production of 50.6 to/ha, favored by the rains of spring 2014 as well as the existence in the past (8-10 years) of the summer cattle camp of the farm's cows on that land.

Agricultural machinery used for the production of hay were:

- Tractor U-445 in aggregate with a rotary mower GMD-44 (fig. 3) to the work of mowing;

- Tractor U-445 in aggregate with double rake GRS-24 (fig. 4) for scattering and gathering the furrow.

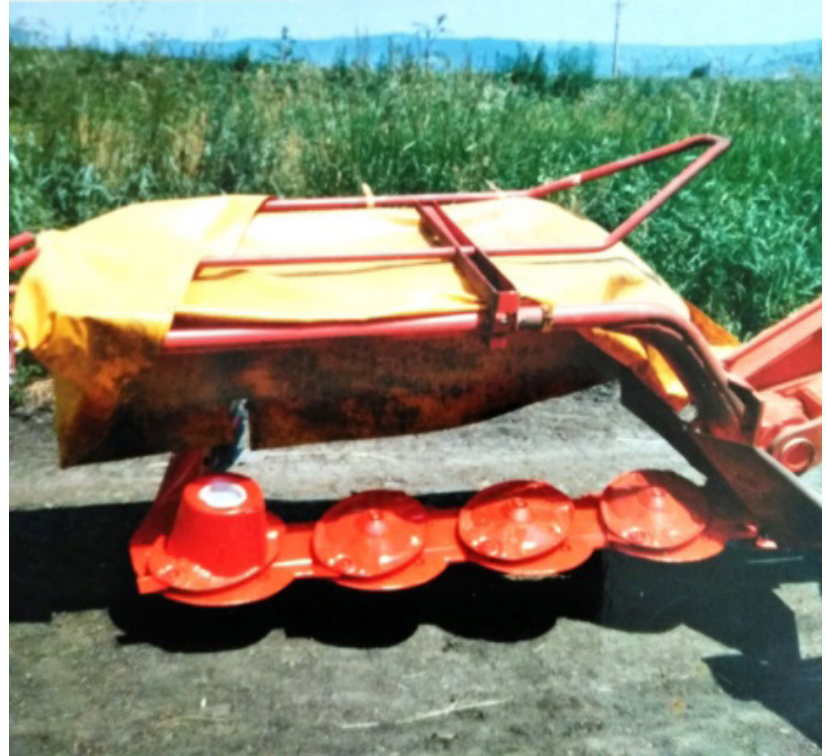

Fig. 3. Rotary mower GMD

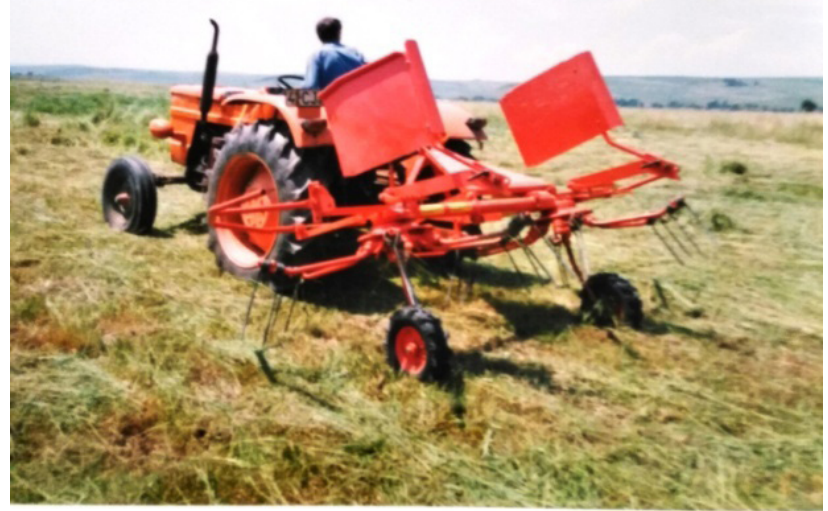

Fig. 4. Rotary rake GRS 24

Were determined by fuel consumption, the effective productivity of aggregates, as well as the qualitative work indices such as: working width of the aggregate, uniformity of plant pruning, the uniformity of the land, the loss of feeding stuffs to furrows gathering, depending on the speeds of displacement.

\section{RESULTS AND DISCUSSION}

The ground on which we have set our experiences is typical of the area, namely molded (argilic) with groundwater to over $2 \mathrm{~m}$ in depth. In terms of physical characteristics (Tab. 1) of soil it is characterized by a loamy texture on all the clay content profile, being in the horizon $A_{m} 42$ $48 \%$ and $\mathrm{B}_{\mathrm{t}}$ horizon $49-51 \%$, index of structural 
Tab. 1. Physical and hidrophysical features of soil in the experimental field, S.D.E. Jucu

\begin{tabular}{|c|c|c|c|c|c|c|c|c|c|}
\hline \multirow[t]{3}{*}{ Profile } & \multirow[t]{3}{*}{ Level } & \multirow{3}{*}{$\begin{array}{l}\text { Depth } \\
\text { (cm) }\end{array}$} & \multicolumn{4}{|c|}{ Granulometrical structure (\%) } & \multirow{3}{*}{$\begin{array}{l}\text { Coeff. } \\
\text { Нy (\%) }\end{array}$} & \multirow{3}{*}{$\begin{array}{c}\text { Withering } \\
\text { coeff. } \\
\% \text { from } \\
\text { weight }\end{array}$} & \multirow{3}{*}{$\begin{array}{c}\text { Field } \\
\text { capacity } \\
\% \text { of } \\
\text { weight }\end{array}$} \\
\hline & & & \multicolumn{2}{|c|}{ Sand (mm) } & \multirow{2}{*}{$\begin{array}{c}\text { Dust } \\
0.02- \\
0.002 \\
\text { (mm) }\end{array}$} & \multirow{2}{*}{$\begin{array}{c}\text { Clay } \\
<0.002 \\
(\mathrm{~mm})\end{array}$} & & & \\
\hline & & & $\begin{array}{c}\text { Coarse } \\
2-0,2\end{array}$ & $\begin{array}{c}\text { Fine } \\
0,2-0,02\end{array}$ & & & & & \\
\hline \multirow{6}{*}{1} & $A_{n}$ & $0-15$ & 0.57 & 29.7 & 24.0 & 45.7 & 10.0 & 16.0 & 24.06 \\
\hline & $A_{m}$ & $25-40$ & 0.97 & 33.6 & 23.4 & 42.0 & 11.0 & 14.7 & 23.83 \\
\hline & $\mathrm{AB}$ & $65-80$ & 0.58 & 19.8 & 14.9 & 55.7 & 13.0 & 19.5 & 24.69 \\
\hline & $B_{t} 1$ & $120-135$ & 0.66 & 35.5 & 13.9 & 49.9 & 13.2 & 17.5 & 24.32 \\
\hline & $\mathrm{B}_{\mathrm{t}} 2$ & $170-185$ & 0.27 & 35.8 & 12.3 & 51.6 & 12.2 & 18.1 & 24.43 \\
\hline & $\mathrm{C}$ & $210-225$ & 0.72 & 34.0 & 15.3 & 50.0 & 10.2 & 17.5 & 24.33 \\
\hline \multirow{6}{*}{2} & $A_{p}$ & $0-15$ & 0.90 & 34.2 & 17.6 & 47.3 & 9.6 & 16.6 & 24.16 \\
\hline & $A_{m}$ & $30-45$ & 1.09 & 21.8 & 29.1 & 48.0 & 10.3 & 16.8 & 24.20 \\
\hline & $\mathrm{AB}$ & $75-90$ & 1.06 & 20.5 & 21.7 & 56.7 & 14.1 & 19.9 & 24.81 \\
\hline & $B_{t} 1$ & $120-135$ & 1.06 & 26.3 & 16.1 & 56.5 & 13.8 & 19.8 & 24.78 \\
\hline & $\mathrm{B}_{\mathrm{t}} 2$ & $185-200$ & 0.79 & 27.1 & 20.1 & 51.0 & 12.2 & 17.8 & 24.39 \\
\hline & $\mathrm{C}$ & $210-225$ & 0.81 & 23.1 & 15.0 & 49.1 & 10.0 & 17.0 & 24.10 \\
\hline
\end{tabular}

Tab. 2. Chemical features of the soil in experimental field, S.D.E. Jucu

\begin{tabular}{|c|c|c|c|c|c|c|c|c|c|c|}
\hline $\begin{array}{l}\text { Pro- } \\
\text { file }\end{array}$ & Level & $\begin{array}{l}\text { Depth } \\
\text { (cm) }\end{array}$ & $\mathrm{pH}$ & $\begin{array}{c}\mathrm{CaCO}_{3} \\
(\%)\end{array}$ & $\begin{array}{c}\text { Humus } \\
(\%)\end{array}$ & $\begin{array}{c}\mathrm{N} \\
\text { total } \\
(\%) \\
\end{array}$ & $\begin{array}{c}\mathrm{P}_{2} \mathrm{O}_{2} \\
\text { (mg/100 } \\
\mathrm{g} \text { gol) } \\
\end{array}$ & $\begin{array}{c}\mathrm{K}_{2} \mathrm{O} \\
\text { (mg/100 } \\
\mathrm{g} \mathrm{sol}) \\
\end{array}$ & $\begin{array}{c}\mathrm{T} \\
\text { (mg/100 } \\
\text { g sol) }\end{array}$ & V\% \\
\hline \multirow{6}{*}{1} & $A_{p}$ & $0-15$ & 5.80 & & 8.81 & 0.416 & 4.4 & 39.5 & 43.4 & 67 \\
\hline & $A_{m}$ & $25-40$ & 6.02 & & 7.33 & 0.329 & 0.6 & 22.0 & 43.0 & 75 \\
\hline & $\mathrm{AB}$ & $65-80$ & 6.42 & & 3.27 & 0.154 & 0.2 & 27.0 & 37.3 & 81 \\
\hline & $B_{t} 1$ & $120-135$ & 7.18 & & & & 0.2 & 22.0 & & \\
\hline & $\mathrm{B}_{\mathrm{t}} 2$ & $170-185$ & 7.88 & 0.9 & & & 1.0 & 18.7 & & \\
\hline & $\mathrm{C}$ & $210-225$ & 8.44 & 8.0 & & & 1.1 & 22.8 & & \\
\hline \multirow{6}{*}{2} & $A_{p}$ & $0-15$ & 6.05 & & & 0.259 & 2.4 & 22.8 & 37.1 & 72 \\
\hline & $A_{m}$ & $25-40$ & 6.36 & & & 0.220 & 0.3 & 21.0 & 34.9 & 79 \\
\hline & $\mathrm{AB}$ & $65-80$ & 6.38 & & & 0.136 & 0.2 & 26.5 & 35.3 & 80 \\
\hline & $B_{t} 1$ & $120-135$ & 6.60 & & & & 0.1 & 25.0 & 32.8 & 87 \\
\hline & $\mathrm{B}_{\mathrm{t}} 2$ & $170-185$ & 7.20 & 0.2 & & & 0.4 & 23.3 & & \\
\hline & $\mathrm{C}$ & $210-225$ & 8.02 & 7.9 & & & 1.1 & 21.0 & & \\
\hline
\end{tabular}

differentiation between horizon $A_{m}$ and $B_{t}$ over 1.20 .

Coefficient of withering is very high by about $16 \%$ in horizon $\mathrm{A}_{\mathrm{m}}$ and $19 \%$ in the horizon $\mathrm{B}_{\mathrm{t}}$ and the capacity of field for water is $24 \%$ by weight, resulting in rapid transition from layer saturated in water the withering $(24-16=8 \%)$.

Chemical characteristics of soil show a weak acid reaction in horizon $A_{m}$, neutral to $B_{t}$ horizon and into the horizon $\mathrm{C}$ alkaline (Tab. 2). Content in hummus is good to very good, and the content of total nitrogen also. Mobile phosphorus is ensured poorly towards the middle in the top $50 \mathrm{~cm}$, and very weak in depth, and potassium is well stocked to very well.

Cationic exchange capacity (T) has high values and the degree of saturation in the alkaline $(\mathrm{V} \%)$ is in the oligo-mezoalkaline. In conclusion clay named chernozem studied is a soil clayey-sandy, rich in humus and nutrients except phosphorus. 
Tab. 3. Thermal regime $\left({ }^{\circ} \mathrm{C}\right)$ and rainfall regime $(\mathrm{mm})$ in condition of Jucu village (Cluj county) in year 2014 (Surce: Meteorological station Jucu belongs to USAMV Cluj-Napoca)

\begin{tabular}{cccccccccccccc}
\hline & Jan & Feb & Mar & Apr & May & Jun & Jul & Aug & Sept & Oct & Nov & $\begin{array}{c}\text { Dec } \\
\text { Average/ } \\
\text { sum }\end{array}$ \\
\hline $\begin{array}{c}\text { Multi-annual } \\
\text { average thermal } \\
\text { regime } \\
\left({ }^{\circ} \mathrm{C}\right)\end{array}$ & -4.5 & -2.3 & 3.2 & 9.1 & 14.3 & 17.5 & 19.3 & 18.3 & 14.3 & 9.1 & 3.3 & 1.6 & 8.3 \\
\hline $\begin{array}{c}\text { Multi-annual sum, } \\
\text { pluvio-metric } \\
\text { regime (mm) }\end{array}$ & 27.0 & 27.2 & 27 & 51 & 74.5 & 99.0 & 91.4 & 77.5 & 50.0 & 43.0 & 28.0 & 17.1 & 612.7 \\
\hline
\end{tabular}

Tab. 4. Fuel consume, effective productivity, speed and gear step for mowing and gathering obtained for experimental and control plots.

\begin{tabular}{|c|c|c|c|c|c|}
\hline Plot & Work & Gear step & Speed $<\mathrm{km} / \mathrm{h}>$ & $\begin{array}{c}\text { Fuel consume } \\
<\mathrm{l} / \mathrm{ha}>\end{array}$ & $\begin{array}{c}\text { Effective Productivity } \\
<\text { ha } / \mathrm{h}>\end{array}$ \\
\hline \multirow{2}{*}{$\begin{array}{l}\text { Experimental plot } \\
<28.5 \text { to/ha }>\end{array}$} & \multirow{2}{*}{ Mowing } & III M & 6.54 & 6.84 & 0.78 \\
\hline & & I R & 8.18 & 4.48 & 0.98 \\
\hline \multirow{2}{*}{$\begin{array}{c}\text { Control plot } \\
<50.6 \text { to } / \text { ha }>\end{array}$} & \multirow{2}{*}{ Mowing } & II M & 3.67 & 10.31 & 0.41 \\
\hline & & I R & 7.48 & 5.48 & 0.83 \\
\hline \multirow{2}{*}{$\begin{array}{l}\text { Experimental plot } \\
<28.5 \text { to/ha }>\end{array}$} & \multirow[t]{2}{*}{ Scattering } & I R & 7.0 & 1.28 & 2.09 \\
\hline & & I R & 8.9 & 1.18 & 2.15 \\
\hline \multirow{2}{*}{$\begin{array}{l}\text { Control plot } \\
<50.6 \text { to } / \text { ha }>\end{array}$} & \multirow[t]{2}{*}{ Scattering } & III M & 4.74 & 2.04 & 1.05 \\
\hline & & II R & 10.3 & 1.04 & 2.23 \\
\hline \multirow{2}{*}{$\begin{array}{c}\text { Experimental plot } \\
<28.5 \text { to/ha }>\end{array}$} & \multirow{2}{*}{ Gathering } & I R & 6.37 & 1.53 & 1.71 \\
\hline & & I R & 6.84 & 1.57 & 1.78 \\
\hline \multirow{2}{*}{$\begin{array}{c}\text { Control plot } \\
<50.6 \text { to } / \text { ha }>\end{array}$} & \multirow{2}{*}{ Gathering } & III M & 5.91 & 3.64 & 1.13 \\
\hline & & II R & 8.15 & 1.50 & 1.79 \\
\hline
\end{tabular}

Temperatures and precipitation throughout the year 2014 as $8.3^{\circ} \mathrm{C}$ annual average, and a total annual rain was $612.7 \mathrm{~mm}$ (Tab. 3).

Fuel consumptions and effective productivity and highlighted the synthetic Tab. 4 reveals significant differences in fuel economy for the harvest work (mowing) on the control parcel (10.3 L/ha) compared with $6.8 \mathrm{l} /$ ha experimental plot, as well as lower productivity on the parcel.

\section{CONCLUSIONS}

1. Grassland soil taken in study type is molded with a high coefficient of withering (16-19\%) and a small capacity water output (8\%). Chemical characteristics of soil samples shows us a good content in humus and good to very good in mobile potassium, being deficient in phosphorus mobile.

2. The climatic conditions of the area were employed in the D.f.b.x. subtype $\mathrm{k}$ "with an average temperature of $8.3^{\circ} \mathrm{C}$ and annual rainfall of $612.7 \mathrm{~mm}$, the spring of 2014 being richer in precipitation than the average of previous years what has fostered the growth and development of plants on both plots.

3. The differences noted between the fuel consumptions for the two parcels is due to higher vegetable production of control plot which has also a running speed of different aggregates also influencing effective productivity.

\section{REFERENCES}

1. Bărbieru VA (2006). Maşini şi instalații zootehnice Construcție, funcționare şi reglaje. Editura Risoprint ClujNapoca

2. Bungescu ST, Popa CI (2007). Mașini și instalații zootehnice, Editura Eurobit, Timişoara.

3. Molnar - Irimie A (2016). Finite element method study on stress state in soil induced by agricultural traffic (in press)

4. Dobre P., Farcaş N., Udroiu NA, Gâdea M, Moraru AC (2014). Research on Camelina sativa wintering, by genotype and fertlizer doses used, in the pedo-climatical conditions from the south of Romania, Romanian Biotechnological Letters, 19(6): 9964-9973 